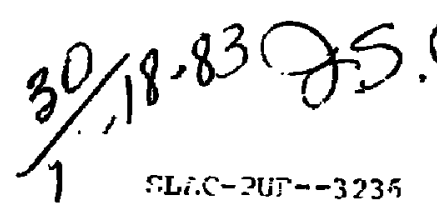

DEat on27!:
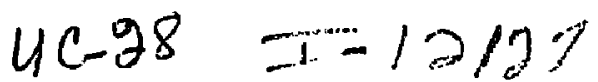

Status of the IEEE PBg6 Future backolane bus"

David B. Gustarson

Stanford Linear Accelerator Center Stanford thiversity, Stanford, Californis 94305
SLAC-PUB- 3236

Octaber 1983

(I)

\section{Dr. $1935-6$}

\section{Abstract}

The IEEE PB96 Future Buckplane But project has been Influenced by and has intluenced FASTBUS and several other contemporary bus desiens. This paper summarizes the curpent status of thet project, which is directed toward the needs of modern 32-bit microprocessor systems with multiple processars.

Some of the technologr developed lor PB96 will be important for future non-ECL implementations al FA5TBus and other buseb. In parileular, new bus frivers and pecelvers should greatly improve the performance and rellability of backplane butes and cable butes.

The current satus of the Po96 sorial bus Is also summarlzed.

\section{Introduction}

The IEEE Pa96' project began as on outgrowth of standardization work on the S-100 bui (IEEE 696) and Multibis (IEE 796 ) in 1978, becoming an independent prolect in lune 1979. There has been a long history of Interaction between the IEEE PO96 project and the FAstous ${ }^{2}$ (IEE P960) prolect. Both prolects are desiening 32 -bit addres/data multpleked buses, but FASTBus Interconnects multiple multiprocessor backplane bus segments and cable bus segments, while $P B 96$ is single multiprocessor backplane bus.

This paper will use FRSTzUS as peference model with which to compare P896, on the assumption that this audience is generally famillar with and has an interest in FASTBUS olready.

P896 Is more closely tailored to the needs of microprocessors, dealing with the problems of byte addressing and part-word eranafert. FAstous is optimized mare for large data-acquibition systems. and supports only full-word eddressine and full-word transfers on the bus.

PQ96 has had a lone and peinful evolution, and has nearly become extlnce severat times along the way. but now appears likely to reach completion.

\section{The Evoluzlon of P896}

PB96 stapted with aenerally-perceived need for a 32-bit high-perfarmance bus siandard. Many Individuals jained the effort, anxlous to see an elezont design which would solve their past and future system problems. Representatives of various industrial concerns appeated as wetl, but the ones in the microprocesso: business, whose needs 9896 was presumably addresilng, did not usually stay long. Cenerally they expressed doubis that such a commitree could do anrthine useful and timely in a subtle crea like computer bus deslen, and left to continue independent work on proprietary buses.
Several manulacturess offered their own bus desicns as a basis lor standardiation. All were examined and rejected, though cometimes with useful cililclsms which wese idopted by the manulacturer to Improve his propiletary product. A subset of FAstbus was proposed ond imliarly rejected,

Then a signlticant Eupopean influence appeared, In the form of an EDIS? (European Distrlbuted Intelligence Study Group iubgroup. Uut of th/s collaboration came abus design which was prototyped and tested, wrlten up as a drafteandard, and submitied to the supervising committee of pag6, the Microprocesior standards Commlttee of the iEE Computep socletr.

Thls draft was relected by the MSC in January, 1782. on the grounds that it falled to meet the ipeed oblectlve and that tho electrical speclflcation was nol adequate for rellable aperailon. This rejection caused the resignation of the Pag6 chairmmn, and the prolect neerly died durline the neke rear because of personnel turnover ond divergent opinions within the working group. The (ourth (and present) chairman was able to tevive wlde Interest by bringing in mony new participants with relevan: experlence, and has kepe the prolect on aligh schedule, producing the ppesent draft 6.1b which is about to be considered by the isc.

The speed problem was telated both to the electsical problems and to the cholce o handshake protocol, which wai optlmized for permilting intervention by : third-parey bus supervicop. The handshake protocol was speeded up by adopting modifted form of the FAST US protocol, sacrificing supervisor Interven. ilón capability.

Enaminarion of the problems of the electricel specification led to a deeper understanding of the physics of buses, and after considerlng many approaches to a solution, a new type of bus cranscelver ${ }^{3}$ was developed by a manufacturer to meet the needs.

The commlitee has been falply consistently In agreement thas the po96 bus will be packaged in the IEC seandard 'Eurocard" mechanical structure, and will use the "DIN 96-pin" (IEC 603-2) connector. There has been strone pressure from time to cime to have a 64-pln subset itandard, but due to the passage of time and the avallability of competing buses and the difficulty of deflating a comparible subset, this pressure has now naarly vanlshed.

The 96-pin connector turns out 20 be serere constraine in the dealgn of 32-bit bus (FASTBUS uses 132 plas), which has helped keep the commirces from addine features recklessly, whatever the technical shortcomlngs of the connec

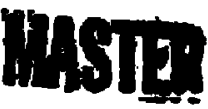

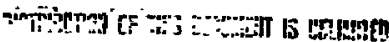

- Work supported by the Department of Enerey under concruct number DE-AC03-765fo0515.

Invited paper presented at the Nuclear Scfence Symposium, San Francisco, Calffornta, October 19-21, 1983. 
Another point of gonepal agreement has been the principle of distributed control, permitting no central failure points except the bus and terminators. This hat led to significant complications relative to FASTBus in the bus arblitration and broadcast mechanisms.

Technology independence. in the form of a fully asynchronaus protocol, has also been accepted as. requirement. Though it is not posslble to make a perfectly sisnchronous sytem (tlmeouts and skew delays violate the principle), Pa96 has carried the principle about as far as possible, again paring some price in complexity.

However, Pags is now also putsuine trnehroaous rersion based on the UIT Nubus es developed by Western Diflitel and Texas Insecumente, with modificetions due to Interaction with Ineel's Muleibus- I and others in the pags committee. The synchronous version is to share the electrical and mechenical speciffcetions with the esynchponous verilon, and be compalible otherwlse where possible. Goth verslons are expected to iupport the same functionallity.

This effort was motivated by a proposal from the developers of the $M I T / W$ Testein DIglial/T I Nubus, and by the Information that the induster's new highperformance buses are mostly gotns to be synchronous, ere. Multibus-ll, The backers clalm that synchronous buses are much simpler, easiep to test in production environmente, and that they are now faster then the atrichionous buses and wlll remaln so for severul years. Furthermore, ospnchronous buses are eachlns fundsmental physics limits whleh will prevent them from ever becoming much faster than today's iynchronous buses.

Despite the partlcipanta' claims that each company is willing to bend soward a sngle standard, it seems tikely that none will bend far enough, because of their own propiletery laterests, and bo a future P896 bynchronous bus will llkely be just one of a family of industry stendards. These buses will share much more commonality then they would have if there had been no P896 interaction, however.

Oiscussions in the P896 forum have bentitted industry and users in many ways, and these benelits alone would be enough to make PQ96 a worthwhile - frort even if no useful standard ever emerged from the commistet.

\section{Intergetion with FASTBUS}

P896 adopted the bastic fASTbus arbitratlon mechanism, as did IEEE 696, but with modifications to make it folly asynchrosous and to elfminate the centrol arbitration control used by Fastaus.

FASTBUS adopted an atbieration protocol which ie calls Assured Access from PB96, where it is called fairness. This protocol llows cound-robin scheduling of most bus users regardless of priority. eliminating bus starvation of law-priorlty modules, while permitting serict priority schedullag of a few

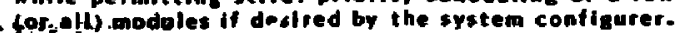
* Fits subseavently chenged its scheme sealn, to a C Father less. elegant one, parily because pogit now uses a module's postition on the bachplane at its normal arbleration prtorlty. An extra arbitration blt was added, to bignal the use of stifict prlorlty and to provlde on idditional set of pilopity levels which are independent of poslelon. A second additional arbieration bit wai addad to provide pertily checking.
Since each bit adds significant delay In today's P696 cechnologr, the non-essentlal bits leem likely candidates for future remoral when actual performances are measured.

PB96 has also adopted a modifled form of the FASTBUS protocols and handshakes for lits aspnchranous version. Some of the differences are arbiirary, but others reflect differences in the gath of the bus, or ditferent oplnions bout the best inadeolf of complexity versus central shared contiol in order to achleve the best rellabllity.

FASTBUS uses two handahake lignals, AS and A K, 10 control the addresiling and connection of the two communicating devices. For broadcests, the $A \mathrm{~K}$ response is senerated br o central plece of logic on the beck of the beck. ane, since no individual module can be selected to nvide It, FBg6 adds a chiro signal, AI, whlch is logical inverse of $A K$, and which sllows the slows st module on the backplane to set the timlng of the operotlon. Thus, the flest responder causes the as-mrton of $A K$, but $A I$ will nol be demasserted untll th lost responder's response. This relfes an wi $=0 R$, wlth lts tronslent problems so integration of Bignals and additional delay in the master is required fanother violation of iree asrinchionous philosophr). Simblatly, P896 adds DI to the FASTBUS OS and DK so that the slowest responder contrate the iransfer pate, whlle FASTBUS generates all re sonses In the backplane support logic, and pelles on modules meting a minimum-speed speciflcatis 7 for brosdcast cycles.

The P896 broadcast protoc. combined with bytelane-disable signals which in turn oft the active drivers, thus provides the capabllity for cycle-bycrcle intervention by a thlid party, such as the bus supervisor provided in the prevlous diatt. However. Pag6 did not ascept the FASTBus WT (wait) slendi which FASTBUS uses for diagnostic purposes In lieu of the supervlsor concept, and so no provlsion exlsts for dlagnostic intervention except during broadcast.

In FASTBUS, the RD read signal is on bus line and is timed so that it can be used to steer the bus interfoce chips directly. PQ96 includes the read agnal In a command fleld instead, and uses it duelng the address cycle to provide d warning to a processor that the following cycle is a rad or wite. Durlng data crcles, the read algnal applites to the current cycle itsoif Instead. FAstaUs allows. mixeure of single word and block transfers to a given address during a given connection, by providing eppropilate sienals on dedicated control lines. PB96 uses the command field during data cycles to control byte-wide dota lanes for part-word transfers, and can thus only signal the type of transter during the sddress cycle.

The fastius protocals wera designed ta support elrcuit-switched Interconnection of multiple bus secmenes dynamically, as requlred. PB96 avolds this mode of operafion entirely, and relles on packet forwarding, ett:-ars etc. for inter-bus communicaclon. However, Pl96 permits multiple buses on the multiple backplane connector positions of the Eutocard system. Thus a processor mey choose from several buses to avold coniention and to provide redundant pathe foi lellable communleatlan. NonPB96 bures are als? allowed to oceupy these connectors, providing convenient way to interface to different bus for $1 / 0$ or other putposes.

Pog has $2^{32}$ bytes addressable on the backplane, 
whlle EAst Bus has $2^{32} 32$-blt words addressable In the entife connected system. Pagr uses part of this a Adress space for cccessing control and status regititars if a module position-dependent way. allowlng $2^{20}$ brees per modyle. FASTBUS provides each module with lis own $2^{32}$-word internal address space for contiol and siatus reglseters, by using en additional cycle to cransfer the internal address polnter. and allows connection either through a position-dependent (geopraphlc) address or through any of the module's normal logical addresses.

\section{Bug-Orivini Technology}

FAsTeus was forced to the ECL (Emitter Coupled loglc) technolosy or tus performance considerations which showed severe disadrantages to the wae of the usuel TTL open-collector or tribtate bus itanaceivers, and PQ96 has also deserted pure TTL for thase reasong. However, semiconductor Industry support of PosG development has resuled in the design of speelal bus iranseelveis ${ }^{3}$ which eliminate the $T T L$ disadvantages while retaining TTL characteristics on the ilde away from the bus. These circults use slew-rate limiting and filtering in the receiver to $11 \mathrm{~m} / \mathrm{n}$ te crosstalk and many other klnds of noise, and have low cspactiance and high impedance to eliminale bus loading and impedance shlfting. They also use low voltage swing to contribute to these performance objectives.

Though the use of special elreults violates a hlghly desirable objective of PB96, the problem is so severe ihat thli step Is necessary. Buses whlch use TTL of CMOS drivers presently only work if they incorporate (perhaps Inadvertently) delays which allow the bus to deetle flef iransitions, or if the buses are not losded in worst-case manner.

The fundamental problem is that the tmpedance of even a well-designed backplane is greacly reduced due to the distributed capacltance of connectors, plug-in board traces, and transcelvers. Furthermole, the impedance varies from point to point along the backplane, depending on the distribution of pluged-in boards. In order to achieve rellable, glich-free signaliing on both risling and falling edges of signals. it is necessary to terminate the bus with the plicht compramise values of resistors and to drive the bus with enough current so that turning of - driver centertes en adequace instancaneous voltage swing. That voltage step must be large enough to carry the signal above the threshold for iriggering the recelvers, and star above the threshold oven after reflections due to imperfect termination or varring Impedance arrive.

The optimum terminetion reslstors may be qulte small. P896 specilties 39 ohms at each end. Ordinary TTL drivers cannot supply enough current lor TiL logic vollage swings (well over 100 milliamperesl, and bave other undesirable properties such as very fast edge transltion rates. Reducing the voltage swing and controlling the edge rates bilings the problem under control, however, when a tecelver with colresponding speciflcations is used. In addition, adding an lsolating diade In series with the diviver reduces the capaclitive loading of the bus sienificantly.

A sulsable transcelver is under development at National semiconductor, ts a result of interaction with Pag6. Three parts are planned: an oceal transcalver. DS3096, wh common enable signals; a quad iranscelver with independent drivers and receivers and common enables os well os individuel driver enables; and an octal verslon of the original DS3662, the DS3862, without the capscitancereducing difiver lisolation diodes, optimbed for cable cimings. Sample quantities of these elrevirs are expecied during the first quarter of 1904 . Furthermore, other manufacturera have expresed willingness to second-source them.

F Astaus, meanwhile, is developing another solution to a bus-driving problem, usine differentlal current sources to lllow irve superposition and wire-OR behevior on dilferential cable bus.

\section{The Serlal Bus}

The Serial bus concept, which wos introduced to FAstBus as part of the dlagnostle srotem, has been edapted In Pag6 in adiferent lotm and for obher reasons. Oeher industry buses heve olso adopted the idea, and an effort is underway to bring all to: single giandard.

There are many different apinlons about what the use of the serial bus should be, if enr. Some think of li a general-purpose metwork; some wlih to use lt as a redundant, though alow, communteatlon path il the parallel bus should fail; some think it hould implement special functiona that the paraltel bus cannot handle easlily; and others think le should be removed to free two pint for other uss.

This divergence whin the commlttee seems to mirrop the divergence within the induatry, so lis is not cleap whether any single standard can develop and survive. Multibus-ll, for example, expects to provide a seplal-bus equivalent for every parallelbus function: this would seem likely to be incompatible with other serlal-bus deslani.

The version of the serial bus in the currons PBgG draft is falily general-purpose, provlding for emergency system control, $1 / 0-1 y p$ activily, and providing facillties for suppofting certaln types of multiprocessor task dispatching aleorlthms. It is an optional feoture, howevef, and is not relied on in any way by the porallel bus.

\section{References}

1. 896/06.1b, A Proposed Stendard Geckolane Bus Speclification for Adrenced Mlcrocomputer Syscems, July 1983, cusilable from Paul Borrill, Chairman, IEE E PA96 Working Group, University College London, Mullard Space Sclence Laboratory, Holmbury St. Mary, Dok KINC, Surrey, RHS GNT, England.

2. Fastbus Specifleatlon, November 1982 (Rev. 15 July 1983), U. S. NIM Committee, erullable from L. Costrell, Dept. of Commerce, National Bureau of Standards, Washineton, DC 20234.

3. R. V. dalakplshnan, 'Cut Bus Reflectlons, Crosilalk with Trapezoldal Transcelver". EOEN August 4, 1983, pp 151-136.

4. D. B, Gustavion and John Theus, "Wire-ON Logic on Transmission Llnes', IEEE MICRO. June 1983, pp 51-55.

5. A. Colon, L. Pregernig, 1. C. Tarle, and R. Downing, "The FAstbus cable Segment". paper presented at this symposium. 


\section{DISCLAIMER}

This report was prepared as an account of work sponsored by an agency of the United States Government. Neither the Uniled States Government wor any agency thereof, nor any of their employees, makes any warranty, express or implied, or assumes any legal liability of responsibility for the accurscy, completeness, of usefulness of any information, apparatus, product, or process disclosed, or ropresents that its use would not infringe privately owned rights. Reference herein to any speciffic commetcial product, process, or service by trade name, trademark, manufacturer, or otherwise does not necessarily constitute or imply ils endorsement, recom: mendation, or favoring by the United States Government or any agency thereof. The views and opinions of authors expressed herein do not necessarily state or reflect those of the Unjted States Government or any agency thereof. 